[Published in Philosophy and Phenomenological Research 74 (2007):

30-55. Final version posted at <http://www.jstor.org/stable/

$40041026>$.]

\title{
Compassionate Phenomenal Conservatism
}

ABSTR ACT: I defend the principle of Phenomenal Conservatism, on which appearances of all kinds generate at least some justification for belief. I argue that there is no reason for privileging introspection or intuition over perceptual experience as a source of justified belief; that those who deny Phenomenal Conservatism are in a selfdefeating position, in that their view cannot be both true and justified; and that the demand for a metajustification for Phenomenal Conservatism either is an easily met demand, or is an unfair or question-begging one.

\section{The Principle of Phenomenal Conservatism}

I am a broad-minded epistemologist: I believe that epistemic justification is conferred by appearances of all sorts, whether sensory, intellectual, mnemonic, or introspective. In short, I endorse Phenomenal Conservatism:

PC If it seems to $S$ that $p$, then, in the absence of defeaters, $S$ thereby has at least some degree of justification for believing that $p .^{1}$

I take statements of the form "it seems to $S$ that $p$ " or "it appears to $S$ that $p$ " to describe a kind of propositional attitude, different from belief, of which sensory experience, apparent memory, intuition, and apparent introspective awareness are species. This type of mental state may be termed an "appearance." PC holds that it is by virtue of having an appearance with a given content that one has justification for believing that content. We can see that appearances are different from beliefs from the fact that it may appear to one that $p$ while one does not believe that $p .{ }^{2}$ This may happen, for instance, when one takes oneself to be experiencing a sensory illusion, so that one does not believe things are the way they appear; note that one's lack of belief does not typically change the way things perceptually appear. The same holds when one suspects that one's memory, intuition, or introspection is unreliable. For instance, the naive comprehension schema of set theory appears correct (we have an intuition that it is correct), though we know that it is not in fact correct.

Nor should appearances be identified with dispositions or inclinations to form beliefs. ${ }^{3}$ One reason is that one might be so convinced that an appearance was illusory that one was not even inclined to believe its content. One could even be convinced in advance that one was going to experience an illusory appearance, so that there would be no time at which one had the relevant inclination to believe. Another reason for distinguishing appearances from dispositions to believe is that the way things appear may provide non-trivial explanations for what we are disposed to believe. I am disposed to accept that there is a white cat on the couch because that is the way things appear to me, and this is not just to say that I am disposed to accept that there is a white cat because I am so disposed. Relatedly, an individual can be disposed to believe a proposition for reasons that do not involve the proposition's seeming to be the case. For example, I might be disposed to believe that I will go to heaven after I die, not because this seems true, but because I want it to be true. Its appearing to one that $p$, again, is a distinct mental state that sometimes leads one to believe that $p$, rather than being the belief or inclination to believe that $p$ itself. 
Some epistemologists are less tolerant than I. Empiricists reject intuition as a source of justification, while indirect realists reject sensory experience as a source of justification in the intended sense. ${ }^{4}$ Laurence BonJour defends a view on which introspection and intuition, but not sensory experience, produce prima facie justification for beliefs. ${ }^{5} \mathrm{I}$ have defended Phenomenal Conservatism, in part, on the grounds that the rejection of Phenomenal Conservatism is selfdefeating - roughly, I argue that if PC is false, then no one has any justified beliefs, not even a justified belief in the negation of PC.

In the following, I elaborate the self-defeat argument and defend it against objections raised by BonJour. First, I address the question of why one should not adopt a more restrictive epistemological theory on which only some appearances confer epistemic justification. I argue that no epistemically relevant distinction can be drawn among appearances that would enable some of them but not others to confer epistemic justification. Second, I address the question of whether an alternative epistemological theory can avoid the charge of self-defeat. I consider four views - BonJour's theory, the acquaintance theory, reliabilism, and skepticism - and argue that, perhaps contrary to initial appearances, none of them escapes self-refutation. Finally, I respond to a further objection raised by BonJour, according to which my thesis of Phenomenal Conservatism stands in need of a metajustificatory argument to show that beliefs formed on the basis of appearances are in general likely to be true. On one interpretation, this metajustificatory demand is easily met; on another, it is difficult to meet but is also unfair or question-begging.

\section{Should We Discriminate Among Appearances?}

I treat all species of appearances as equally valid sources of justification. I take it that the critic who believes that only some appearances should be accepted as sources of justification incurs a burden of identifying an epistemically relevant difference between those appearances that do and those appearances that do not confer justification on their contents. In this section, taking Laurence BonJour as an example of such a critic, I consider whether BonJour's views provide a basis for identifying such a distinction.

\subsection{Privileging Introspection}

On BonJour's view, introspective beliefs about one's own mental states are based upon a kind of self-awareness that is built into all conscious mental states. When I have a conscious pain, for example, the pain experience contains an awareness of itself and of its own phenomenal properties. This built-in awareness is infallible, in the sense that it cannot be present without one's actually being in pain. ${ }^{6}$ BonJour does not, however, claim that introspective beliefs are infallible. He allows that one can make errors in passing from one's introspective awareness to a judgment. Such errors can result from inadequate attention, the obscurity or complexity of the proposition that one uses to describe one's experience, and other problems.

Imagine, then, that $S$ has a conscious mental state, $m$, with an intrinsic feature, $F$-ness. $S$ has an infallible awareness of this mental state. I do not know exactly how Bonjour would characterize this awareness-perhaps as the awareness that $m$ is $F$, or the awareness of $m$ 's $F$ ness, or simply the awareness of $m$. Regardless, suppose that $S$ makes an error in introspective judgment, resulting in the belief that $m$ is $G$, where $G$-ness is some property that $m$ does not in fact have. $S$, however, has no specific grounds for suspecting that he has made an error. Is $S$ justified in believing that $m$ is $G$ ? BonJour says yes:

$[\mathrm{I}$ t would still be possible to apperceptively misapprehend one's own belief, that is, to have 
a second-level belief that does not accurately reflect the content contained in the constitutive or "built-in" awareness constitutive of the first-level belief.... But unless there is some special reason in a particular case to think that the chances of such a misapprehension are large, this possibility of error does not seem to prevent the secondlevel metabelief from being justifiable by appeal to the first-level constituent awareness. This is just to say that while such justification is defeasible in various ways, it is adequate until and unless it is defeated, rather than requiring an independent show of reliability. ${ }^{7}$

In short, the view is that $S$ is justified in believing that $m$ is $G$, on the basis of the awareness of $m$ that is built into $m$. BonJour is wise to take this stance, enabling him to locate the foundations of empirical knowledge in introspective beliefs, without having to say that the mistaken introspector is unjustified merely because he is mistaken.

It is puzzling, however, how the awareness that $m$ is $F$ - or the awareness of $m$ 's $F$-ness, or the awareness of $m$ - could justify a belief that $m$ is $G$, where $m$ 's being $G$ does not follow from its being $F$ and where $m$ is not in fact $G$. It is difficult to formulate a reasonable principle of justification, significantly different from Phenomenal Conservatism, that would have this result. Consider the following alternatives:

(1) If one is introspectively aware that $\Phi x$, and $\Psi$ is some property distinct from $\Phi$, then one thereby has at least some defeasible justification for believing that $\Psi x^{8}$

(2) If one is introspectively aware that $\Phi x$, and $\Phi x$ renders it probable that $\Psi x$, then one thereby has at least some defeasible justification for believing that $\Psi x$.

(3) If one is introspectively aware that $\Phi x$, but one's awareness seems to oneself to be the awareness that $\Psi x$, then one thereby has at least some defeasible justification for believing that $\Psi x$.

(4) If one is introspectively aware that $\Phi x$, but it seems to oneself that $\Psi x$, then one thereby has at least some defeasible justification for believing that $\Psi x$.

I cannot create a complete list of possible views. But discussion of these four positions should indicate the difficulties facing a defender of BonJour's position. Notice first that theory (1) is absurdly liberal-one's introspective awareness of a mental state does not justify one in believing just any claim about that mental state. A defender of BonJour's position must identify something special about the content of the false introspective belief in my example, presumably consisting of some special way in which the proposition that $m$ is $G$ (or the property of $G$-ness) is related to one's introspective awareness of $m$ 's $F$-ness, some way in which most propositions about $m$ 's characteristics (or most possible properties of a mental state) are not related to that introspective awareness.

(2) is plausible, particularly for those with BonJour's view of justification, ${ }^{9}$ but it does not enable the belief that $m$ is $G$ to be justified. Consider one putative example of introspective error. It is sometimes suggested that, in considering the question of whether it is necessary that water is $\mathrm{H}_{2} \mathrm{O}$, philosophers of an earlier, pre-Kripkean era mistook the intuition that the thing with the surface properties of water (a.k.a. "the watery stuff') might not have been $\mathrm{H}_{2} \mathrm{O}$, for an intuition that water might not have been $\mathrm{H}_{2} \mathrm{O}$. Though this caused philosophers to falsely believe that it was contingent that water is $\mathrm{H}_{2} \mathrm{O}$, philosophers never had a false intuition; they merely mistook the content of their intuition. Even if this common account of this case is not correct, there almost certainly exist legitimate examples of false introspective beliefs about which I might make similar remarks to the following. ${ }^{10}$ It hardly seems that one's having an intuition with the 
content that the watery stuff might not have been $\mathrm{H}_{2} \mathrm{O}$ renders it probable that the intuition in question actually has the content that water might not have been $\mathrm{H}_{2} \mathrm{O}$. Indeed, it would seem that the proposition that one's intuition has the former content rules out that it has the latter content, insofar as those contents are distinct (assuming that an intuition can have only one proposition as its content). For this sort of reason, (2) fails to explain how typical false introspective beliefs can be justified.

(3) and (4), in my view, are correct, and it is (4) that most nearly explains why the belief in question is justified. It is because $m$ seems to $S$ (albeit falsely) to be $G$, while $S$ lacks any grounds for doubting this, that $S$ is justified in believing that $m$ is $G$. But both (3) and (4) are too close to Phenomenal Conservatism for BonJour's purposes; indeed, if one accepts (4), one ought simply to embrace Phenomenal Conservatism. For it is difficult to see why (4) would be true, unless the appearance that $\Psi_{x}$ provided at least some justification for one to believe that $\Psi_{x}$. It hardly seems that the introspective awareness that $x$ is $\Phi$ would contribute to explaining this justification; if anything, it would seem that the awareness that $x$ is $\Phi$ should interfere with one's being justified in believing that $x$ is $\Psi$, given that, as we have seen, in at least some typical cases, $x$ 's being $\Phi$ rules out its being $\Psi$. Thus, I see no role for the infallible awareness that BonJour posits in explaining the justification for the introspective belief in this case.

The problem I have posed for BonJour applies generally to theories that would privilege introspection over perception while recognizing the possibility of false but prima facie justified introspective beliefs. The problem is one of identifying some justification-conferring factor that may be present in the case of a false introspective belief but is not present in the case of typical perceptual beliefs. It is difficult to see what might justify false introspective beliefs other than their merely seeming to the subject to be true.

My argument here parallels one deployed by Richard Fumerton against some versions of direct realism. ${ }^{11}$ Fumerton argues, roughly, that a very vivid, detailed hallucination provides the same sort of justification for believing its content that a normal perceptual experience does. But the hallucination does not constitute direct awareness of its supposed object and thus does not confer justification in virtue of such direct awareness. Therefore, a normal perceptual experience also does not confer justification for believing its content in virtue of constituting direct awareness of its object. I think this argument succeeds in showing that perceptual experiences do not confer justification for beliefs by virtue of constituting direct awareness.

Similarly, I argue that a false introspective belief may have the same sort of justification as a correct introspective belief. But a false introspective belief is not justified by virtue of one's having direct awareness of the putative fact that it represents; instead, it is justified by virtue of its seeming to the subject that there is such a fact, or that he is directly aware of such a fact. Therefore, correct introspective beliefs are also not justified by virtue of one's having direct awareness of the facts they represent; instead, they are justified by the appearances.

\subsection{Privileging Intuition}

BonJour's view of the epistemology of intuition, or "apparent rational insight," differs from my view of the epistemology of appearance in at least three ways. ${ }^{12}$ First, BonJour believes that an intuition provides justification for belief only if the intuition follows a reasonably careful consideration of the proposition intuited. I place no such restriction on the ability of appearances to confer justification; even an appearance that results from a cursory glance at a proposition confers some degree of justification on its content, in the absence of defeaters. Second, for BonJour, an intuition must involve an apparent awareness of the necessity of the 
proposition in question, whereas in my view, appearances may confer justification on propositions that by no means seem necessary, including propositions about the present arrangement of physical objects around one. Third, BonJour tentatively suggests that all mistaken intuitions can in principle be corrected by further reflection on those intuitions-in his words, intuitions are "internally correctable" — whereas this is not true of such appearances as perceptual experiences; a victim of vivid hallucination need have no internal means of coming to know that his experience is hallucinatory.

None of these points reflects an epistemically relevant difference between perceptual experience and intuition. Begin with the first point, the requirement of carefulness. If we were convinced of the need for such a qualification, we could impose a similar condition on all appearances. We could say that one must look (listen, etc.) reasonably carefully before one's visual (auditory, etc.) experience provides one with justification for beliefs about the physical world. This requirement would provide a basis for discriminating against perceptual experience only if for some reason, we were unable to or universally failed to exercise adequate care in making perceptual judgments. But this is not the case.

Nevertheless, it is true that, if such a requirement of due care is appropriate, then Phenomenal Conservatism as I have formulated it is overly permissive. Why do I not include a requirement of carefulness in my statement of PC? Briefly, I believe that this requirement seems to us an appropriate one only because we think — reasonably enough — that carelessness is conducive to error, while carefulness is conducive to reliability, or at least a higher degree of reliability. If we were not justified in believing that, then it would be equally rational for us to accept intuitions that resulted from careless consideration as it would to accept those that resulted from careful consideration. It is difficult to imagine a case in which we would not be justified in believing that carelessness was conducive to error, but I believe such a case would be possible; we could discover that whenever we thought too long before making an intuitive judgment, we were more likely to make a mistake. In such a situation, we might be inclined to include a requirement of cursoriness in our account of when intuitions conferred justification, rather than the requirement of carefulness that BonJour finds plausible. But that just shows that neither condition belongs in a fundamental epistemological theory. The correct fundamental epistemological theory will be a necessary truth that, when combined with the contingent circumstances of a world, yields appropriate verdicts on which beliefs in that world are justified. The theory of Phenomenal Conservatism yields the conclusion that in our world, carelessly formed beliefs are typically ill-justified, even if they strongly seem to the subject to be true, because their would-be justification is defeated, since we are generally justified in believing that careless belief-formation is unreliable. BonJour's view differs from mine in that on his view, an intuition following a cursory examination could never provide justification for belief, even if we had no reason to regard such intuitions as unreliable.

Next, consider the apparent necessity of a priori intuitions, as contrasted with perceptual appearances. Though I am inclined to agree that all apparent rational insights seem necessary, while no perceptual appearances do, I do not find this difference epistemically significant. It seems to me that the apparent necessity of a priori insights would be epistemically relevant only if the fact that they seem to be necessary constituted some justification for believing that they are necessary. But if its seeming to $S$ that $p$ is necessary confers some justification for believing that $p$ is necessary, then one would think that something's seeming to $S$ to be the case, in general, should confer some justification for believing that that thing is the case. I see no reason, in other words, why propositions of the form "it is necessary that $p$ " should be inherently more easily justified than propositions of other forms, in the sense that only the former sort of propositions 
may be rendered justified merely by their appearing to be the case.

Bonjour might argue that, since intuitions strike us as necessary, we thereby have an account, supported by the intuitions themselves, of why our beliefs in the propositions we intuit are more than just accidentally true. An analogous argument could be made for perceptionthough observations do not strike us as necessary, we have an account, based on observation, of why observational beliefs are non-accidentally correct. Granted, our observation is not infallible (nor, as BonJour admits, is intuition), but we can explain the general reliability of observation, roughly, in terms of the ways our sense organs are hooked up to our environment. And it seems as though observations have at least as much by way of internal coherence going for them as a priori intuitions do.

Finally, consider the alleged internal correctability of intuition, a notion that BonJour explicates as follows: "Further reflection on the very state or process that led to the mistaken result is capable of revealing that it was a mistake and of replacing it with the correct result." 13 It does not seem that this is generally true of intuitions. Consider the intuition supporting the comprehension axiom of naive set theory. It does not seem that further reflection on that intuition itself - as opposed to further argumentation relying on other intuitions-would have revealed that this was a false intuition. What revealed that the intuition supporting the naive comprehension axiom was false was the discovery of set theoretic paradoxes resulting from that axiom. This was not a matter of mere further reflection on the intuition or the process that led to it; rather, it was a matter of deploying further intuitions, including the intuition that no proposition that entails a contradiction is true, and further reasoning.

Moreover, whether or not intuition is always internally correctable, this does not seem relevant to intuition's capacity to generate prima facie justification, nor, I think, does BonJour take it to be so. The mere possibility of my correcting my error in the future, should my belief that $p$ be erroneous, does not seem to enhance my present justification for believing that $p$. This possibility does not entail that my present belief is not in error, nor that this belief is any less likely to be in error than, say, a typical perceptual belief. The thesis of internal correctability is compatible with $80 \%$ of all intuitive judgments being false, in circumstances such as those we are actually in, where our intuitive judgments are not in fact made in the light of all possible reflection. Insofar as one understands justification in terms of likelihood of truth, it is thus unclear how internal correctability per se might enhance justification.

\section{Is the Denial of Phenomenal Conservatism Self-Defeating?}

\subsection{The Self-Defeat Argument Revisited}

In earlier work, I alleged that the rejection of Phenomenal Conservatism is self-defeating, roughly, because one who rejected Phenomenal Conservatism would inevitably do so on the basis of how things seemed to himself; he would do so because Phenomenal Conservatism did not seem to him to be correct, or because it seemed to him to be incompatible with other things that seem correct. Therefore, if this opponent of Phenomenal Conservatism were right, his belief in the negation of Phenomenal Conservatism would itself be unjustified.

Here, I want first to clarify the above rough argument. My first premise is an empirical one, to the effect that, when we form beliefs, with a few exceptions not relevant here, our beliefs are based on the way things seem to us. ${ }^{14}$ Indeed, I think that the way things appear to oneself is normally the only (proximately) causally relevant factor in one's belief-formation. In other words, in normal contexts, including that of the present discussion of epistemic justification, one would not form different beliefs unless things appeared different to oneself in some way 
(belief content supervenes on appearances, in normal circumstances). Furthermore, in normal conditions, the way appearances determine beliefs is by inclining one towards believing what appears to oneself to be so, as opposed, say, to our being inclined to believe the things that seem false.

Consider an alternative view. One might argue that we are sometimes caused to believe that $p$ by the fact that $p$. For instance, the fact that there is a cat here might causally explain my belief that there is a cat here, since the cat reflects light towards my eyes, resulting in changes in my brain, and so on. I do not deny this. What I maintain is that the cat's presence causes me to believe that there is a cat here only by causing it to appear to me that there is a cat here. Furthermore, the appearance probabilistically screens off my belief from the external fact. That is, given that I experience exactly the sort of appearance I am now experiencing, the probability of my forming the belief that there is a cat is unaffected by the actual existence or non-existence of the cat. If I have this sort of appearance caused by a cat, I will believe that there is a cat; but equally, if I have the same appearances when no relevant cat exists, I will believe that there is a cat. It is in the light of this sort of consideration that I say the perceptual belief is based on the sensory experience.

This is not to say that everyone who has the sort of sensory experience I now have will form the belief that there is a cat here. Imagine a skeptic who believes that sensory appearances are no guide to the truth, and who manages for a bit to withhold belief in such things as cats. This skeptic is also forming beliefs on the basis of appearances. In this case, the skeptic has certain intuitions (intellectual appearances) that seem to him to imply that one ought not to trust one's senses. These intuitions would underlie the premises of some skeptical argument of the sort with which epistemologists are familiar. ${ }^{15}$

This may not be the only way a conscious being could be constructed. Perhaps there could be beings who spontaneously formed beliefs without first experiencing any appearances. Perhaps there could even be beings who, when it seemed to them that $p$, strangely adopted the belief that $\sim p$. What I am claiming is that upon reflection, we find that we in fact form beliefs on the basis of appearances in the way I have described.

The second premise of the self-defeat argument is, roughly, that if one's belief that $p$ is based on something that does not constitute a source of justification for believing that $p$, then one's belief that $p$ is unjustified. I distinguish here between one's having justification for believing that $p$, and one's having a justified belief that $p$. To illustrate the distinction, suppose that Henry has been exposed to a number of rationally compelling arguments for the theory of evolution. Despite understanding these arguments, Henry refuses to accept them, through sheer stubbornness. One day, Henry's tarot card reader tells him that, based on a recent tarot reading, she has determined that the theory of evolution is true. Henry then finally accepts evolution. At this point, Henry has an unjustified belief in evolution, since his belief is based on trust in a tarot card reader. But Henry has had all along, and continues to have, justification for believing the theory of evolution-he still knows the cogent arguments for evolution, which constitute adequate justification for the theory.

Though justification for believing that $p$ is not to be confused with justified belief that $p$, the two are clearly related in some interesting and intimate way. This relationship, in my view, involves something in the neighborhood of one of the following:

a. $\quad S$ has a justified belief that $p$ only if there is some condition that constitutes adequate justification for believing that $p$, and the obtaining of that condition is the reason why $S$ believes that $p .^{16}$ 
b. $\quad S$ has a justified belief that $p$ only if for some $M, S$ formed the belief that $p$ by means of method $M$, and being the output of method $\mathrm{M}$ is a justification-conferring property.

c. $S$ has a justified belief that $p$ only if there is some condition $C$ that constitutes a source of justification for believing propositions that satisfy $C$, and $S$ 's method of forming the belief that $p$ was that of believing propositions that satisfy $C$.

There is a central intuition that conditions (a), (b), and (c) are all getting at-roughly, that a justified belief must be held because of what provides adequate justification for it. I shall not try to determine the best formulation of this idea, but I assume that something along these general lines is correct.

Given these premises, it follows that no belief is justified, unless one may have justification for believing that $p$ in virtue of its appearing to one that $p$. If, that is, appearances do not confer at least some defeasible justification on propositions that are their contents, then since our beliefs are generally based on what seems to us to be the case (the reason we believe what we do is that it appears true to us; our method of forming beliefs is to believe what seems true to us), our beliefs are generally unjustified. Therefore, if Phenomenal Conservatism is false, those who believe it to be false do so unjustifiedly. The argument here is not directly an argument that Phenomenal Conservatism is true, but rather that epistemological theories that oppose Phenomenal Conservatism are self-defeating.

A number of objections might be raised to the preceding argument, some of which I have addressed elsewhere. ${ }^{17}$ In the following subsections, I consider four alternative epistemological views, each of which may initially seem to avoid self-defeat without embracing Phenomenal Conservatism.

\subsection{A Restricted Phenomenal Conservatism}

The first alternative is what we might call a restricted phenomenal conservatism, according to which some but not all appearances confer prima facie justification for belief. We have already seen that BonJour advances such a view, allowing introspective and intuitive appearances, but not sensory appearances, to confer prima facie justification on their propositional contents. Though I have criticized this view above, our present concern is whether, regardless of whether the view is otherwise defensible, such a restricted phenomenal conservatism provides an interesting way of avoiding the self-defeat argument. Initially, it seems that, provided that the appearances on which the epistemological theory in question is itself based are among those that the theory identifies as justification-conferring, the theory will be self-supporting, rather than self-defeating.

It is not clear to me that this reasoning is correct. Suppose that the correct theory of justification is the following:

RPC $S$ has defeasible justification for believing that $p$ if and only if $(i)$ it seems to $S$ that $p$ and (ii) $R(S, p)$.

where $R$ is some relation that $S$ might stand in to $p \cdot{ }^{18} \mathrm{RPC}$ is the general form of a restricted version of Phenomenal Conservatism. Note that according to RPC, its seeming to $S$ that $p$ alone confers no justification, even defeasibly, on $p$. It is only the combination of this condition with $S$ 's standing in $R$ to $p$ that can confer such justification. Now suppose also that in fact, $S$ believes some proposition $A$ solely because of how things seem to $S$, and that the holding of $R(S, A)$ is 
causally irrelevant to $S$ 's belief formation. Then I would say that $S$ 's belief that $A$ is unjustified, for it is grounded in something that does not constitute justification for believing that $A$. While this factor may constitute part of an adequate source of justification for believing that $A$, it does not by itself provide any justification for believing that $A$.

One who would avoid the self-defeat argument by proposing a restricted phenomenal conservatism, then, must argue not only that there is some epistemically relevant difference between some appearances and others, but also that this difference makes a difference, causally, to what we believe. It is unlikely that this constraint can be satisfied. Consider again the case of BonJour's theory, according to which (a) the infallible self-awareness that is built into our conscious mental states is essential to what makes introspective beliefs prima facie justified, and (b) the apparent necessity of intuited propositions is essential to what makes intuitive beliefs prima facie justified. When one adopts the introspective belief that one is in pain, one does so because one seems to oneself to be in pain, simply, rather than because one seems to oneself to be in pain and pains have a built-in infallible awareness of themselves. One test of this assertion is to ask whether, if it seemed to one that one was in pain, but yet (perhaps per impossibile) it was false that pains had a built-in infallible awareness of themselves, one would still have believed that one was in pain. It seems to me that the answer to this is yes. Similarly, when one adopts the intuitive belief that $1+2=3$, I think that one does so because it seems to one that $1+2=3$, rather than because it seems to one that it is necessary that $1+2=3$. If it had seemed to one that $1+2$ was equal to 3 but yet this had not seemed necessary (as might perhaps happen if one had no concept of necessity), one would still have believed that $1+2=3$. On Bonjour's view, the mere appearance that $1+2=3$ is justificatorily impotent; only the appearance that it is necessary that $1+2=3$ can confer justification on the belief that $1+2=3$. So on that view, those who believe the proposition merely because it seems to be true do so unjustifiedly.

Now setting that point aside, there is a further constraint that a restricted phenomenal conservatism must satisfy in order to avoid the self-defeat charge in an interesting way. This is that the theory should draw a non-arbitrary distinction among appearances, that is, it should identify an epistemically relevant property that only some appearances have. Consider an epistemological theory that might be said to avoid the self-defeat problem, but only in an uninteresting way; call this theory Barely Coherent Phenomenal Skepticism:

BCPS No appearance provides justification for believing its content, except the appearance that this very proposition is true.

What makes this way of avoiding the self-defeat charge uninteresting is that it identifies no epistemically relevant difference between the appearance that BCPS is the case and other appearances, together with the reasonable suspicion on our part that any argument against trusting appearances in general will also apply to the appearance that BCPS is the case. BCPS makes an ad hoc exception to a general epistemological thesis, solely to protect itself. The following position, which I call Arbitrary Phenomenal Skepticism, is not quite as ad hoc, but is equally unsatisfactory:

APS No appearance provides justification for believing its content, unless its content can be stated as a universally quantified conditional.

Again, APS avoids self-defeat, since it can be stated as a universally quantified conditional, but only in an uninteresting way, since there is no epistemically relevant difference between 
appearances that have universally quantified conditionals as their contents and other appearances.

The lesson is that an alternative to Phenomenal Conservatism escapes self-defeat in an interesting way only if it does so without relying on ad hoc or epistemically arbitrary distinctions. As we saw in section 2, it is difficult to identify any relevant distinction marking off either introspective appearances or intuitions from other kinds of appearances.

\subsection{The Acquaintance Theory}

The Acquaintance Theory of non-inferential justification holds that a belief is non-inferentially justified if and only if it is appropriately related to something with which one is acquainted. A simple version of the view is that one is non-inferentially justified in believing that $p$ if and only if one is acquainted with the fact that $p$. Acquaintance is taken to be a suigeneris relation that one may stand in to a fact, a kind of direct awareness of the fact. Note that one's being acquainted with the fact that $p$ entails that $p$ is true ("acquaintance" is factive). Typically, advocates of acquaintance theories take the possible objects of acquaintance to include (facts about) one's own mental states and certain abstract objects. ${ }^{19}$

The Acquaintance Theory is an alternative to Phenomenal Conservatism; acquaintance is not a species of appearance, since acquaintance is taken to be a real relation between a person and an object or fact, whereas an appearance is a non-factive propositional attitude. Though the nature of acquaintance calls for further explication, at least one point of distinction between the Acquaintance Theory and Phenomenal Conservatism is clear: on the Acquaintance Theory, unlike Phenomenal Conservatism, false appearances can provide no non-inferential justification for belief.

The Acquaintance Theory may seem to escape self-defeat, as the Acquaintance Theorist may claim to be justified in believing the Acquaintance Theory, directly or indirectly, on the basis of facts with which he is acquainted. ${ }^{20}$ If the self-defeat argument of section 3.1 were concerned solely with our justification for various propositions, this defense would succeed; the Acquaintance Theorist has no obvious difficulty maintaining that we have justification for believing the Acquaintance Theory of non-inferential justification. The argument, however, is concerned with whether we possess justified beliefs. I have argued that, if Phenomenal Conservatism is false, we have no justified beliefs, even if we have available justification for various propositions. To escape self-defeat, an epistemological theory must identify as an adequate source of justification something that our would-be justified beliefs, including the belief in the very epistemological theory in question, are in some sense based on. My claim is that when one believes without inference that $p$, one believes that $p$ because it appears that $p$, rather than because one is acquainted with the fact that $p$. This is supported by the fact that if things appeared to one exactly the same in the relevant respects (that is, with respect to $p$ and propositions that bear on $p$ ), but one was not actually acquainted with the fact that $p$, then one would believe that $p$; and if one were acquainted with the fact that $p$ but (perhaps per impossibile) it did not appear to one that $p$, then one would not believe that $p$.

Consider again two examples discussed in section 2. First, the naive comprehension axiom of set theory: philosophers believed this proposition because it seemed true, though no one was ever acquainted with any corresponding fact, since the axiom is not in fact true. It may, of course, have seemed that we were acquainted with a corresponding fact, but according to the Acquaintance Theory, this is not enough; it is only the actual relationship to a corresponding fact that confers non-inferential justification. Second, the case of the false introspective belief 
that one has the intuition that water might not have been $\mathrm{H}_{2} \mathrm{O}$, where one's intuition actually has the content that the watery stuff might not have been $\mathrm{H}_{2} \mathrm{O}$ (again, should one find this example problematic, any false introspective belief will do): philosophers held this belief because it seemed correct to them, rather than because they were acquainted with a corresponding fact. In this case, the only fact with which philosophers might have been acquainted was the fact that they had the intuition that the watery stuff might not have been $\mathrm{H}_{2} \mathrm{O}$, but they did not come to believe this (until Kripke). The Acquaintance Theory implies that both the naive set theory belief and the belief that one intuits that water might not have been $\mathrm{H}_{2} \mathrm{O}$ were unjustified. Indeed, the Acquaintance Theory has difficulty recognizing any cases of non-inferentially justified but false belief. That is a problem for the theory, but not the problem on which I focus here. I maintain that, even more troublingly, the Acquaintance Theory implies that even in cases where our intuition or introspection is correct, we still do not acquire justified beliefs. This is because, when one has a correct intuitive or introspective belief, one's belief has the same sort of basis that it does in cases of mistaken intuitive or introspective beliefs-namely, it too is based on how things appear to us. If, per impossibile, the naive comprehension axiom had turned out to be true, but the world had otherwise been like the actual world, then presumably philosophers' belief in the naive comprehension axiom at the beginning of the twentieth century would still have had the same sort of basis that it actually had. And there is no reason for thinking that this basis is different from what it is in typical cases where we correctly intuit a necessary truth. As we have seen, the Acquaintance Theory denies that this basis constitutes a source of epistemic justification.

The Acquaintance Theorist is on stronger ground when it comes to certain introspective beliefs, particularly those concerned with qualitative, conscious mental states. It is plausible to maintain that, when I introspectively believe that I am in pain, my belief is directly caused by the pain; it is plausible to deny that any distinct, intermediary state of "appearing to be in pain" is required. While I am sympathetic to this line of thought, I believe it is compatible with Phenomenal Conservatism. The Phenomenal Conservative maintains that, when one introspects a conscious pain, one typically comes to believe that one is in pain because it seems to one that one is in pain, but we need not construe the seeming to be in pain as a separate state from the pain. We might regard the state of seeming to be in pain and the state of being in pain as token identical - this being a self-referential mental state. I take this to be essentially the view that BonJour endorses when he speaks of the built-in self-awareness that conscious mental states have. If this is right, then we can maintain both that introspective pain-beliefs are caused by the actual pains that they are about and that they are caused by the appearance of pain-the appearance of pain, so to speak, is its reality.

This is not true of other things with which one might be acquainted, such as abstract objects and perhaps the intentional contents of mental states, which are more relevant when it comes to discussing the justification for epistemological theories. Whatever foundational beliefs the Acquaintance Theory itself is based on will presumably include some abstract beliefs, such as beliefs about the nature of justification, whose truth is not guaranteed by their appearing to be true. It is with respect to this sort of belief that appearance is significantly different from acquaintance, and it is here that the Acquaintance Theory has difficulty granting us justified belief. Again, in cases where there is a clear distinction between appearance and acquaintance, it is appearance that explains our beliefs, rather than acquaintance. Consequently, the Acquaintance Theorist cannot account for why belief in the Acquaintance Theory is justified. 


\subsection{Externalist Alternatives}

Reliabilism, which I take as representative of externalist accounts of justification, holds roughly that a belief is justified if and only if it is formed by a reliable method. ${ }^{21}$ This theory may appear to avoid self-defeat, since the reliabilist can maintain that his belief in Reliabilism was itself formed by a reliable method. But again, the question is not whether, on Reliabilism, we might have justification for believing Reliabilism; the question is whether those who believe Reliabilism have a justified belief. There are two interpretations of Reliabilism. On the first interpretation, the view is that a property of a belief is justification-conferring if and only if beliefs with that property are highly likely to be true. On the second interpretation, the view is that there is exactly one justification-conferring property: the property of being the outcome of a reliable belief-forming method.

On the first interpretation, Reliabilism is compatible with Phenomenal Conservatism. Provided we accept that appearances are usually correct, Reliabilists may say that a thing's seeming to be the case confers justification for believing it. In this case, the Reliabilist escapes self-defeat.

On the second interpretation, Reliabilism is incompatible with Phenomenal Conservatism, which holds that something's seeming to be the case confers justification for believing that thing - this property is distinct from that of being the outcome of a reliable belief-forming method, even if believing things that seem to be the case is itself a reliable method. Is this form of Reliabilism subject to the self-defeat argument? Again, the issue turns on what our actual beliefs are based on. In my view, our beliefs are typically explained by the way things appear to us, rather than by the fact that particular beliefs are the outcomes of reliable belief-forming processes. That the actual reliability of a process has no independent causal relevance can be seen from the fact that if things appeared to one the same, but one's belief-forming processes were unreliable, one would still hold the same beliefs; conversely, if some reliable belief-forming process would lead to the belief that $p$, but it does not seem to one that $p$, nor does $p$ seem to be supported by anything else that seems true to one, then one will not believe that $p$.

The problem applies generally to externalist theories, where these are theories that identify some factor external to the mind as an essential component of what provides justification for belief. Such external factors can be at most indirectly causally relevant to our beliefs-they affect what we believe, if at all, only by affecting how things appear to us, and once the appearances are fixed, external factors have no independent relevance. If two subjects have the same appearances but external factors differ, they will have the same beliefs. Thus, consider the infamous brain-in-a-vat scenario: the brain in the vat believes exactly what we believe, because everything appears to the brain exactly the way it appears to us, even though for the brain, perceptual beliefs are highly unreliable. The externalist is committed to saying that the brain is the repository of a vast array of unjustified beliefs. ${ }^{22}$ Worse, the externalist must say that our perceptual beliefs are unjustified. Intuitively, the brain in the vat's beliefs have the same sort of basis as our beliefs, that is, the brain believes what it does for the same reason that we believe what we do. This is true even if perceptual beliefs are non-inferential - the reason why both we and the brain believe what we do about our immediate environment is that we have sensory experiences representing the world as being a certain way-in short, we believe certain things about the external world because they perceptually appear to be the case. This, rather than any real relation to the external world, is clearly why the brain believes what it does; so, when we reflect on the intuition that the brain believes what it does for the same reason we believe what we do, we should conclude that these same appearances, rather than a real relation to the 
external world, are the reason why we believe what we do. And this, according to externalism, is not a sufficient source of justification for belief; therefore, according to externalism, our actual beliefs are unjustified.

\subsection{The Skeptical Alternative}

A final alternative is to capitulate to the global skeptic, conceding that all our beliefs are unjustified. As BonJour writes:

[T] he fact that we ultimately have nothing else to rely on [than appearances] does not show that the claims that we accept on this basis are likely to be true or that we have good reason to think they are. ... [I]f Huemer's defense of the reliance on perceptual experience is the best that we can do, the result, I submit, is skepticism about the resulting claims rather than genuine justification. ${ }^{23}$

BonJour and I have a basic methodological disagreement: I regard the avoidance of skepticism as a high priority for epistemological theory, because I view skepticism as prima facie extremely implausible. BonJour is much more willing to entertain skepticism.

Nevertheless, BonJour's remarks do not adequately address the self-defeat problem, even for one who takes skepticism seriously. BonJour's remarks seem to overlook the broad scope of the claims regarding justification involved in the self-defeat argument. According to that argument, if Phenomenal Conservatism is false, then no belief is justified, including skeptical beliefs; nor is any reasoning cogent, including BonJour's reasoning. ${ }^{24}$ BonJour reasons that if I am right that all our beliefs are based on appearances, but there are no better arguments for Phenomenal Conservatism than those I have put forward, then, since those arguments were inadequate for various reasons, all our beliefs are unjustified. But this reasoning itself is impotent if the assumptions involved in it are true. If I am right that essentially all of our beliefs are based on appearances, this includes beliefs based on arguments, including the argument just stated - in essence, such beliefs are based on the appearances that the relevant premises are true and that they support the relevant conclusions. Thus, the skeptical response to the self-defeat argument should be rejected because it is itself self-defeating.

Here BonJour might be expected to reiterate something like his original response: "Granted, the skeptic's position may be self-defeating, but that does not show that your position is justified." But one could sincerely make such a response only if one either did not attend to the fact that one was oneself expressing a judgment or argument in doing so, or one believed that it was possible to express a judgment or argument while remaining at most neutral on the question of whether that judgment or argument had any rational force. And I think that is not possible; one who holds any position at all, even a skeptical position, is at least implicitly committed to the belief that his acceptance of that position is to some degree justified. ${ }^{25}$ In consistency, therefore, one must accept that the basis on which one holds one's belief is a source of justification - and so, I maintain, one must accept Phenomenal Conservatism. Now, I have not here given an argument adequate for rationally convincing one who holds no beliefs at all to accept Phenomenal Conservatism-but then, as Aristotle says, such an individual is "no better than a vegetable." ${ }^{26}$ All those animate individuals who make judgments and undertake reasoning, BonJour very much included, are implicitly committed to Phenomenal Conservatism.

Self-defeat arguments of this sort are not infrequently met with suspicion, as though this type of argument were inherently less cogent, or less legitimate, than more direct arguments for 
a thesis. This, in my view, is a mistake; if alternatives to Phenomenal Conservatism are really self-defeating for the reasons I have given, this constitutes at least as powerful a reason for accepting Phenomenal Conservatism as any argument can ever provide. For if an argument can ever provide a reason for accepting a conclusion, then something must be to some extent justified. But, if we grant that the denial of Phenomenal Conservatism engenders global skepticism with respect to justification, the only further assumption required to derive that Phenomenal Conservatism is true is that something is to some extent justified. It seems to me that this is literally the least we could assume, in any discussion; therefore, the move from the claim that the denial of Phenomenal Conservatism implies global skepticism, to the claim that Phenomenal Conservatism is true, would seem to be at least as rationally persuasive as any inference. ${ }^{27}$

\section{The Demand for Metajustification}

BonJour takes the concept of justification, plausibly enough, to be tied to the notion of likelihood of truth in such a way that justified beliefs must be likely to be true. For an epistemological theory of the form, "If a belief has $\Phi$, then it is justified," a metajustificatory argument would be an argument designed to show that beliefs with $\Phi$ are likely to be true. Sometimes, BonJour takes epistemological theories to stand in need of such arguments. In his earlier, anti-foundationalist incarnation, BonJour took foundationalism to be vitiated by the failure to satisfy the demand for metajustification. ${ }^{28}$ Similarly, his core objection to Phenomenal Conservatism is that there is no obvious reason for thinking that beliefs based on appearances would be likely to be true.

But BonJour does not always impose a demand for metajustification on epistemological theories. In particular, he finds the demand for an argument to show that beliefs based on intuition are likely to be true misplaced:

The dialectical picture that such a demand in effect assumes is one in which apparent rational insight has no epistemic value in itself, but instead functions merely as a kind of earmark or symptom for picking out a class of believed propositions that the supposedly required metajustificatory premise then tells us are, on some independent ground, likely to be true. ... But from the standpoint depicted in the previous chapter, this is obviously the wrong picture and amounts simply and obviously to a refusal to take rational insight seriously as a basis for justification: a refusal for which the present objection can offer no further rationale, and which is thus question-begging. ${ }^{29}$

I agree with BonJour's response on behalf of the rationalist to the demand for metajustification. The rationalist picture that BonJour develops takes intuitions as themselves sufficient (with some qualifications) for justification. One does not, on this view, infer the proposition in question from the premise that one has a certain sort of intuition; rather, by having an intuition, one is (seemingly) immediately aware of some particular necessary truth, and in virtue of that, one is non-inferentially justified in believing the relevant proposition. It would certainly beg the question to object at this point that intuitive beliefs are not justified unless we can provide reasons for them - that would simply be to assume that intuitive beliefs are not foundational as the rationalist supposes. But if it would beg the question to assume that we need reasons for our intuitive beliefs, presumably it would also beg the question to assume that we need reasons for thinking that our intuitive beliefs are true. While there may be a distinction between a reason for 
believing that $p$ and a reason for thinking that one's belief that $p$ is true, this distinction is not significant enough to enable the demand for the latter sort of reason to avoid begging the question against an epistemologist who takes $p$ to be foundational, when the demand for the former sort of reason begs the question so transparently. Similarly, if it begs the question to demand a reason for believing that intuitive beliefs are true, it surely also begs the question to demand a reason for believing that intuitive beliefs are likely to be true, which is what the metajustificatory demand does. If we need no reason for thinking that $p$ is true, then presumably we also need no reason for thinking that $p$ is likely to be true.

All of this applies equally well to the case of perceptual experience and belief. The direct realist takes perceptual beliefs to be foundationally justified, no less than the rationalist takes intuitive beliefs to be foundationally justified. The direct realist view is not that we first notice that we have a perceptual experience with a certain character, and then infer that the external world is a certain way. And just as it would beg the question to object that the rationalist has failed to supply reasons for our intuitive beliefs, it would beg the question to object that the direct realist has failed to supply reasons for our perceptual beliefs. Again, the distinction between a reason for a belief and a reason for thinking that the belief is likely to be true does not seem significant enough to enable the demand for the latter sort of reason to escape the charge of question-begging, when the demand for the former sort of reason begs the question so transparently. ${ }^{30}$

So far I have been interpreting the metajustificatory demand, applied to some epistemological theory, as a demand for a reason, applicable to every belief the theory identifies as justified, for believing that those beliefs are likely to be true. A slightly different metajustificatory demand would be a demand for a reason for believing the following general proposition: Probably, most of the beliefs that are justified according to the theory are true. This demand does not appear to beg the question against foundationalism as the former demand does. Is it a legitimate demand to impose on epistemological theories?

To answer this, we must first examine the notion of probability involved in the metajustificatory demand. In what sense should it be shown that most of one's beliefs would probably be true? First, suppose we adopt a physical interpretation of probability - for instance, a frequency or propensity interpretation. In that case, the metajustificatory demand assumes epistemic externalism, for the physical probability of a proposition is typically determined by factors external to our minds, to which we may lack access. Since both BonJour and I reject externalism about justification, let us set this interpretation aside.

Second, suppose we adopt a purely subjective interpretation of probability, in terms of subjects' degrees of belief. In that case, there is no difficulty in showing that our beliefs are likely to be true; if likelihood is just defined in terms of our degrees of belief, it is analytic that our beliefs are likely to be true. Of course, those who accept a subjective interpretation of probability impose some constraints on subjective probabilities: our degrees of belief must satisfy the axioms of probability to be considered "probabilities." A Phenomenal Conservative, too, might reasonably add the axioms of probability to his theory as constraints on rational systems of belief. The important point is that on a subjective interpretation of probability, the metajustificatory demand poses no particular threat to Phenomenal Conservatism.

Third, suppose we adopt a logical or epistemic interpretation of probability. On such an interpretation, the probability of a proposition is the degree of justification one has for believing it, or the degree to which one's total evidence supports it. On this interpretation, the metajustificatory demand, applied to a particular epistemological theory, amounts in essence to a demand to show that we are justified in believing that most beliefs that are justified according to 
the theory are true.

We might try to satisfy this demand from within the theory of justification in question. That is, we might try to show that the proposition, "Most beliefs that are justified according to the theory are true," has the property that our epistemological theory says makes propositions justified. It seems reasonable to expect that this should be the case for any comprehensive theory of justification. In the case of Phenomenal Conservatism, we might try to show that the proposition, "Most of the things that seem true to us are true," seems true to us, or is supported by things that seem true to us. Well, it certainly seems to me that most of the things that seem to me to be true are true. It seems to me that there is a table here, and that's true. It seems to me that $2+2=4$, and that's true. It seems to me that I exist, and that's true. When I think about examples like this, it seems to me that my appearances are reliable-in short, that most of them are true.

BonJour might reject this approach to his metajustificatory requirement. He might insist that I show that we are justified in believing "Most beliefs that are justified according to PC are true," without relying on PC itself. To see why this demand is unfair, imagine that some day, a brilliant epistemologist discovers the correct, comprehensive theory of justification. It is:

CTJ $S$ is justified in believing that $p$ if and only if $\Phi(S, p)$.

BonJour then imposes his metajustificatory requirement. He asks that the brilliant epistemologist produce an argument to show that we are justified in believing the following proposition, without relying on CTJ:

M Most of the propositions that bear $\Phi$ to us are true.

Why should we assume that it would be possible to do this? We would not make such an assumption for justified propositions in general-we have no reason to assume that in general, if $S$ is justified in believing that $p$, it will be possible to show that this is so without relying on the correct theory of justification. This might be so-in some cases, one might show that $S$ is justified in believing that $p$ by appealing to pre-theoretical intuitions, for example. But since there is no reason for assuming that this must be so in general, and there seems to be no special reason for thinking that it must be so for propositions like $\mathrm{M}$, we should not impose the general demand that the advocate of an epistemological theory give an argument for a proposition of the form of $\mathrm{M}$ without relying on his own epistemological theory; in general, we should not impose a requirement on epistemological theories if, assuming we had a correct epistemological theory, we have no reason to think that the correct theory would satisfy that requirement.

Perhaps I have made the metajustificatory demand too complex. Perhaps it simply comes down to the demand that the proponent of an epistemological theory should supply a reason for accepting the theory. I have discussed some of the reasons for accepting PC in this paper. We should accept Phenomenal Conservatism, in brief, because our ordinary doxastic practice commits us to it, because alternative theories are self-defeating, and because Phenomenal Conservatism just seems right. ${ }^{31}$

\section{References}

Armstrong, David M. 1961. Perception and the Physical World. London: Routledge \& Kegan Paul. Aristotle. 1941. The Basic Works of Aristotle, edited by Richard McKeon. New York: Random 
House.

Bealer, George. 1999. "A Theory of the A Priori," pp. 29-55 in Philosophical Perspectives 13: Epistemology, edited by James Tomberlin. Cambridge, Mass.: Blackwell.

BonJour, Laurence. 1985. The Structure of Empirical Knowledge. Cambridge, Mass.: Harvard University Press.

BonJour, Laurence. 1998. In Defense of Pure Reason. Cambridge: Cambridge University Press.

BonJour, Laurence. 2001. "Toward a Defense of Empirical Foundationalism," pp. 21-38 in Resurrecting Old-Fashioned Foundationalism, edited by Michael DePaul. Lanham, Md.: Rowman \& Littlefield.

BonJour, Laurence. 2004. "In Search of Direct Realism," Philosophy and Phenomenological Research 69: 349-67.

BonJour, Laurence. 2005. "In Defense of the A Priori," pp. 98-105 in Contemporary Debates in Epistemology, edited by Matthias Steup and Ernest Sosa. Oxford: Blackwell.

Descartes, René. 1984. Meditations on First Philosophy in The Philosophical Writings of Descartes, vol. II, edited by John Cottingham, Robert Stoothoff, and Dugald Murdoch. Cambridge: Cambridge University Press.

Fumerton, Richard. 1985. Metaphysical and Epistemological Problems of Perception. Lincoln, Nebr.: University of Nebraska Press.

Goldman, Alvin I. 1992. Liasons: Philosophy Meets the Cognitive and Social Sciences. Cambridge, Mass.: MIT Press.

Howard-Snyder, Daniel. 1998. "BonJour's 'Basic Antifoundationalist Argument' and the Doctrine of the Given," Southern Journal of Philosophy 36: 163-77.

Huemer, Michael. 2001. Skepticism and the Veil of Perception. Lanham, Md.: Rowman \& Littlefield.

- 2006. "Moore's Paradox and the Norm of Belief' in Themes from G. E. Moore, ed. Susana Nuccetelli and Gary Seay. Oxford University Press.

Locke, John. 1975. An Essay Concerning Human Understanding, edited by P.H. Nidditch. Oxford: Clarendon Press.

Lynch, Michael. 2006. "Trusting Intuition" in Truth and Realism, edited by Patrick Greenough and Michael Lynch. Oxford University Press.

Pitcher, George. 1971. A Theory of Perception. Princeton, N.J.: Princeton University Press.

Russell, Bertrand. 1997. The Problems of Philosophy. Oxford: Oxford University Press.

Sosa, Ernest. 2006. "Intuitions" in Truth and Realism, edited by Patrick Greenough and Michael Lynch. Oxford University Press.

Williamson, Timothy. 2000. Knowledge and Its Limits. Oxford: Oxford University Press.

\section{Notes}

1. See my (2001, pp. 98-115). I have modified the principle from its original version: I have inserted "at least some degree of," to make clear that one need not have full justification for belief merely by having, for example, a weak and wavering appearance, and I now treat Phenomenal Conservatism as governing justification in general, rather than only noninferential justification. Thanks to Michael Tooley, who endorses neither version of the principle, for making clear the need for such revisions.

2. Bealer (1999, p. 31), Huemer (2001, pp. 99-100), and Sosa (2006) have argued along these lines.

3. Armstrong (1961,pp. 84-7) and Pitcher (1971, pp. 91-3) propose such an account of sensory appearances, while Sosa (2006) and Lynch (2006) put forward similar views about intuitions. 
4. Empiricists may accept intuitions as a source of justification for some things (such as propositions about one's intuitions), but they do not accept them as a source of justification for the propositions that we intuit. Indirect realists accept sensory experiences as an indirect source of justification for claims about the external world — but they deny that claims about the external world are justified, as the Phenomenal Conservative would have it, merely because they are the contents of certain appearances.

5. BonJour 1998; 2001, chapters 4-5; 2004. BonJour introduces some qualifications, and he allows the possibility of defeaters for intuitive and introspective beliefs. Views that privilege introspection and intuition have a long tradition; see Descartes 1984, Locke 1975, and Russell 1997.

6. BonJour 2001, pp. 24-6.

7. BonJour 2001, pp. 25-6.

8. To have defeasible justification for believing that $p$ is to be in an epistemic position such that, if there were no defeaters for $p$, then one would have justification for believing that $p$.

9. Bonjour frequently ties the notion of justification to that of likelihood of truth (1985, pp. 8, 31; 2001, p. 23; 2004, pp. 359-60).

10. See Williamson 2000, chapter 4, for an argument that judgments about all types of mental states are fallible.

11. Fumerton 1985, pp. $78 \mathrm{ff}$.

12. BonJour 1998, pp. 114, 116-17.

13. BonJour 1998, p. 116.

14. See my (2001, pp. 55-7) on the "based on" relation. The exceptions concern cases of selfdeception and leaps of faith. I do not mean to imply that these phenomena are rare. But they are not relevant to the present discussion, since presumably the opponent of Phenomenal Conservatism will not claim to base his position on self-deception or faith. There may also be exceptions involving victims of severe disorders such as brain damage or insanity.

15. As this case illustrates, one can be moved to believe (or withhold) $p$, not only by its seeming (or not seeming) to oneself that $p$, but also by one's believing that $p$ is or is not justified, or that one should or should not believe $p$. But that belief must in turn be based on something, and I would argue that at some point, one must believe something because it seems to oneself to be true.

16. This does not require that $S$ 's belief that $p$ be inferential-for example, "the reason why" I believe there is a white cat on the couch may be that I have a visual experience of one, though my white-cat belief is not a product of inference.

17. See above, note 1.

18. I use "relation" in the broad sense used by logicians; thus, for example, " $R(S, p)$ " could mean " $p$ is a proposition about $S$ 's mental states" or even " $p$ is a necessary truth."

19. Russell (1997) and Fumerton (1995, pp. 73-9) defend versions of the Acquaintance Theory, though Fumerton's view is more complex than the view I have sketched in the text. Fumerton (1995, p. 77) also suggests that acquaintance with a fact merely similar to the fact that $p$ may produce non-inferential justification for believing that $p$. See Russell (1997, chapters 5,10$)$ on the possible objects of acquaintance.

20. Fumerton (1995, p. 77), for example, reports that he knows of the existence of acquaintance by acquaintance.

21. Goldman (1992, p. 116). Goldman refines the view to take account of defeaters (p. 123), but these refinements do not bear on my arguments here. 
22. Goldman (1992, p. 134) confirms this assessment, declaring unjustified the beliefs of victims of Cartesian demons. Though Goldman allows another, "weak" sense of justification in which such beliefs would be justified, I am here interested in his strong sense of justification, the sense that is characterized in terms of reliability.

23. BonJour 2004, pp. 359-60.

24. That is, no reasoning would justify any of our beliefs. Some conclusions might still be rendered probable by their premises, in some sense.

25. I discuss this rational commitment in my (2006).

26. Metaphysics IV.4, 1006a15. Aristotle's approach to the law of non-contradiction is analogous to my approach to PC.

27. BonJour himself-rightly, in my opinion-deploys an analogous self-defeat argument against empiricism, characterizing the repudiation of a priori reasons as a form of "intellectual suicide" (1998, p. 115; 2005, p. 103).

28. Bonjour 1985, pp. 30-33.

29. BonJour 1998, p. 145.

30. Howard-Snyder (1998, pp. 164-5) makes a similar observation.

31. I would like to thank an anonymous referee for Philosophy and Phenomenological Research for helpful comments on this paper. 